\title{
PENGARUH SUHU PENGGORENGAN DAN KETEBALAN IRISAN BUAH TERHADAP KARAKTERISTIK KERIPIK NANAS MENGGUNAKAN PENGGORENGAN VAKUM
}

\section{Effect of Frying Temperature and Slice Thickness of Fruit on Characteristics of Pineapple Chips Using Vacuum Frying}

\section{Asmawit ${ }^{\star}$ dan Hidayati}

Balai Riset dan Standardisasi Industri Pontianak

JI. Budi utomo No. 41 Pontianak

*e-mail: laempaha@yahoo.com

Diterima: 18 Pebruari 2014, revisi akhir: 5 Desember 2014 dan disetujui untuk diterbitkan: 8 Desember 2014

\begin{abstract}
ABSTRAK
Nanas merupakan salah satu buah yang banyak dihasilkan di Kalimantan Barat. Produksi nanas yang relatif tinggi dan umur simpan yang relatif pendek mendasari perlu dilakukan diversifikasi produk dari buah nanas sehingga dapat menambah nilai jual dan memperpanjang umur simpan buah. Salah satu alternatif yang potensial untuk dikembangkan adalah dengan mengolahnya menjadi keripik. Pengolahan keripik nanas dilakukan dengan menggunakan alat penggorengan hampa (vacuum frying). Pada proses pembuatan keripik nanas ini dilakukan penelitian berupa variasi suhu penggorengan yaitu 80,85 dan $90^{\circ} \mathrm{C}$ dan tebal irisan yaitu 3,4 dan $5 \mathrm{~mm}$. Tujuan penelitian ini adalah untuk mengetahui pengaruh suhu penggorengan dan tebal irisan buah terhadap karakteristik keripik nanas. Hasil analisa menunjukkan bahwa suhu penggorengan antara $85-90^{\circ} \mathrm{C}$ dan tebal irisan $3 \mathrm{~mm}$, merupakan kombinasi yang baik dalam pembuatan keripik nanas dan sudah memenuhi SNI 01-4304-1996.
\end{abstract}

\section{Kata Kunci: Karakteristik, keripik nanas, suhu penggorengan, penggorengan vakum}

\section{ABSTRACT}

Pineapple is one of the fruits that are produced in West Kalimantan. The production which is relatively high and it had a relatively short shelf life that is necessary to diversify the products from pineapple fruit that can add the sale value and extend the shelf life. One potential alternative is to develop the processing become chips. Pineapple chips processing was done by using a vacuum frying. The making process of pineapple chips was done by varying of frying temperature at 80,85 and $90^{\circ} \mathrm{C}$ and slice thickness 3,4 and $5 \mathrm{~mm}$. The research goal was to determine the effect of frying temperature and slice thickness of fruit on the characteristics of pineapple chips. The analysis showed that the frying temperature between $85-90^{\circ} \mathrm{C}$ and slices thick $3 \mathrm{~mm}$ were a good combination in the making of pineapple chips and met the SNI 01-43041996.

\section{Keywords: Characteristic, pineapple chips, frying temperature, vacuum frying}

\section{PENDAHULUAN}

Indonesia kaya dengan berbagai produksi hasil hortikultura, antara lain buahbuahan. Namun, berlimpahnya buahbuahan terkadang menjadikannya memiliki nilai jual yang rendah. Bahkan di daerah tertentu, banyak buah-buahan terbuang percuma dan membusuk, karena tidak termanfaatkan. Salah satu cara untuk meningkatkan nilai jual buah sekaligus upaya memperpanjang umur simpan adalah dengan menjadikannya keripik buah. Dengan menjadikannya keripik, nilai jual buah menjadi tinggi. Sebagai gambaran, 1 kg keripik nanas dihargai sebesar Rp 95.000,00 per kg (Komunitas Agrobisnis, 2013).

Pengolahan buah menjadi keripik harus menggunakan alat khusus yang dinamakan 
vacuum frying (penggorengan hampa), karena tidak bisa dibuat hanya dengan menggunakan penggorengan biasa. Hal ini disebabkan karena komoditi buah-buahan hampir semuanya memiliki kandungan glukosa (gula) yang cukup tinggi. Oleh karena itu, apabila mengolahnya dengan cara menggoreng menggunakan alat penggoreng biasa, keinginan untuk bisa berubah menjadi keripik tidak akan terjadi. Buah yang digoreng bisa lembek atau lengket di wajan, yang mengakibatkan tidak layak dijual maupun dikonsumsi.

Menggoreng hampa adalah menggoreng berbagai macam produk dengan kondisi hampa udara. Menurut Lastriyanto (2006), penggorengan hampa dilakukan dalam ruangan tertutup dengan kondisi tekanan rendah sekitar $70 \mathrm{cmHg}$. Penggorengan hampa udara dapat digunakan sebagai alternatif pengolahan bahan yang rentan terhadap suhu yang tinggi. Bahan dipanaskan dibawah tekanan vakum sehingga menurunkan titik didih air dalam bahan (Muchtadi, 2008). Dengan penurunan tekanan maka suhu penggorengan bisa dilakukan relatif lebih rendah dibandingkan suhu penggorengan dengan tekanan atmosfer. Beberapa kelebihan jika buah digoreng dengan mesin penggorengan hampa adalah tidak gosong, kandungan nutrisi tidak hilang, rasa dan aroma sesuai bahan aslinya, renyah, tidak perlu bahan pengawet atau bahan kimia, dan tidak perlu penambah rasa buah buatan (Dwi, 2011).

Penelitian tentang penggorengan hampa telah dilakukan oleh beberapa peneliti sebelumnya seperti Sudjud (2000), melakukan penelitian utama pada penggorengan hampa buah cempedak pada suhu 85,90 dan $95^{\circ} \mathrm{C}$ dengan waktu penggorengan 25,30 dan 35 menit dengan tekanan $10 \mathrm{cmHg}$ diperoleh keripik cempedak terbaik pada penggorengan hampa pada suhu $90^{\circ} \mathrm{C}$ selama 30 menit. Begitu juga dengan Nurhudaya (2011), diperoleh suhu dan waktu yang optimal untuk penggorengan hampa durian menjadi keripik durian berdasarkan hasil pembobotan adalah $75^{\circ} \mathrm{C}$ dan 85 menit. Sedangkan untuk penggorengan hampa ikan balita diperoleh suhu dan waktu yang optimal adalah $105^{\circ} \mathrm{C}$ dan 30 menit (Suseno, dkk., 2008).
Produksi buah nanas di Kalimantan Barat cukup besar yaitu mencapai 108.704 ton pada tahun 2012 (Badan Pusat Statistik, 2013) sehingga perlu dilakukan pengolahan terhadap nanas untuk memperpanjang umur simpannya. Berdasarkan hal tersebut maka dilakukan penelitian tentang pengolahan keripik nanas menggunakan penggorengan hampa, untuk mengetahui suhu dan ketebalan irisan buah nanas yang tepat dalam pembuatan keripik nanas secara vakum.

\section{METODOLOGI PENELITIAN}

Bahan-bahan yang digunakan pada penelitian ini adalah buah nanas dan minyak goreng. Alat-alat yang digunakan dalam penelitian ini adalah penggorengan hampa (vacuum frying), spinner, freezer, pengiris buah, dan alat pengujian kadar air, kadar abu serta kadar minyak/lemak.

Parameter yang digunakan dalam penelitian ini adalah suhu penggorengan dan ketebalan irisan buah. Suhu penggorengan terdiri dari 80,85 , dan $90^{\circ} \mathrm{C}$. Ketebalan irisan buah adalah 3, 4 dan $5 \mathrm{~mm}$. Hasil penelitian ini diharapkan dapat diperoleh kombinasi perlakuan yang baik dalam menghasilkan keripik nanas.

\section{Pembuatan Keripik Nanas}

Proses pembuatan keripik nanas adalah nanas dikupas lalu dicuci dan diiris dengan ketebalan sesuai perlakuan yaitu 3 , 4 dan $5 \mathrm{~mm}$, kemudian dimasukkan ke dalam freezer hingga beku (2-3 jam). Kemudian digoreng dengan menggunakan penggorengan hampa (vacuum frying) dengan suhu sesuai perlakuan yaitu 80,85 dan $90^{\circ} \mathrm{C}$, selanjutnya ditiriskan dengan menggunakan spinner dan terakhir dikemas (packaging).

\section{Analisis Keripik Nanas}

Analisis karakteristik yang dilakukan terhadap keripik nanas yang dihasilkan meliputi kadar air, kadar abu dan kadar minyak/lemak serta dilakukan uji organoleptik. Hasil karakteristik keripik nanas ini selanjutnya dibandingkan dengan SNI 01-4304-1996 tentang Keripik Nanas. 


\section{HASIL DAN PEMBAHASAN}

\section{Buah Nanas}

Buah Nanas (Ananas comosus (L.) Merr.) banyak mengandung vitamin $A$ dan $C$ sebagai antioksidan. Juga mengandung kalsium, fosfor, magnesium, besi, natrium, kalium, dekstrosa, sukrosa, dan enzim bromelain. Bromelain berkhasiat sebagai anti radang, membantu melunakkan makanan di lambung serta menghambat pertumbuhan sel kanker. Kandungan seratnya dapat mempermudah buang air besar pada penderita sembelit. Sekarang, buah nanas juga dapat dibuat keripik dengan rasa alami buah dan tanpa bahan pengawet (Arif, 2013). Kandungan gizi buah nanas dalam setiap $100 \mathrm{~g}$ bahan dapat dilihat pada Tabel 1 (Pangaila, 2010).
Tabel 1. Kandungan gizi buah nanas segar (100 gram bahan)

\begin{tabular}{lr}
\hline \multicolumn{1}{c}{ Kandungan gizi } & Jumlah \\
\hline Kalori $(\mathrm{kal})$ & 52,00 \\
Protein $(\mathrm{g})$ & 0,40 \\
Lemak $(\mathrm{g})$ & 0,20 \\
Karbohidrat $(\mathrm{g})$ & 16,00 \\
Fosfor $(\mathrm{mg})$ & 11,00 \\
Zat Besi $(\mathrm{mg})$ & 0,30 \\
Vitamin A $(\mathrm{SI})$ & 130,00 \\
Vitamin B1 $(\mathrm{mg})$ & 0,08 \\
Vitamin C $(\mathrm{mg})$ & 24,00 \\
Air $(\mathrm{g})$ & 85,30 \\
Bagian dapat dimakan $(\%)$ & 53,00 \\
\hline
\end{tabular}

Sumber: Pangaila, 2010

\section{Karakteristik Keripik Nanas}

Keripik nanas adalah makanan yang dibuat dari daging buah nanas masak, dipotong/disayat dan digoreng memakai minyak secara vakum, dengan atau tanpa penambahan bahan lain dan bahan tambahan makanan yang diizinkan (Badan Standardisasi Nasional, 1996). Hasil analisis terhadap karakteristik keripik nanas yang meliputi kadar air, kadar abu, dan kadar minyak/lemak dapat dilihat pada Tabel 2 .

Tabel2. Pengaruh suhu penggorengan dan tebal irisan buah terhadap karakteristik keripik nanas

\begin{tabular}{|c|c|c|c|c|}
\hline \multirow[b]{2}{*}{ Ketebalan Irisan (mm) } & \multirow{2}{*}{$\begin{array}{l}\text { Suhu } \\
\left({ }^{\circ} \mathrm{C}\right)\end{array}$} & \multicolumn{3}{|c|}{ Karakteristik } \\
\hline & & $\begin{array}{l}\text { Kadar Air } \\
\left({ }^{\circ} \mathrm{C}\right)\end{array}$ & $\begin{array}{l}\text { Kadar Abu } \\
\left({ }^{\circ} \mathrm{C}\right)\end{array}$ & $\begin{array}{c}\text { Kadar Minyak/lemak } \\
(\%)\end{array}$ \\
\hline 3 & $\begin{array}{l}80 \\
85 \\
90\end{array}$ & $\begin{array}{l}7,20 \\
6,47 \\
4,69\end{array}$ & $\begin{array}{l}1,42 \\
1,36 \\
1,77\end{array}$ & $\begin{array}{r}7,19 \\
8,56 \\
12,60\end{array}$ \\
\hline 4 & $\begin{array}{l}80 \\
85 \\
90\end{array}$ & $\begin{array}{c}10,30 \\
10,90 \\
8,33\end{array}$ & $\begin{array}{l}1,54 \\
2,47 \\
3,51\end{array}$ & $\begin{array}{r}10,60 \\
6,40 \\
7,67\end{array}$ \\
\hline 5 & $\begin{array}{l}80 \\
85 \\
90\end{array}$ & $\begin{array}{l}9,28 \\
5,75 \\
4,73\end{array}$ & $\begin{array}{l}2,46 \\
2,33 \\
2,65\end{array}$ & $\begin{array}{r}11,60 \\
11,90 \\
7,85\end{array}$ \\
\hline SNI 01-4304-1996 & & maks. 5 & maks. 3 & maks. 25 \\
\hline
\end{tabular}




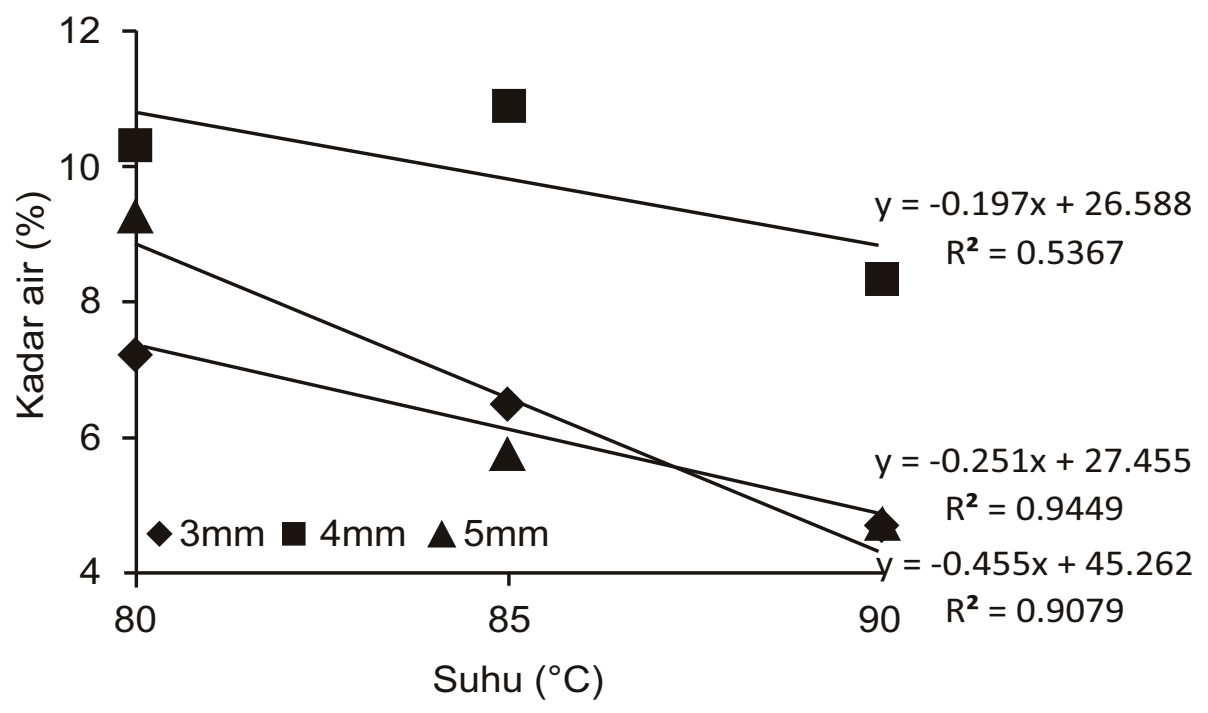

Gambar 1. Grafik kadar air keripik nanas

\section{Kadar Air}

Menurut Rahmawati (2008), semakin tinggi suhu yang digunakan maka semakin besar air yang menguap, sehingga air yang terkandung dalam keripik buah akan berkurang. Kadar air keripik nanas terendah diperoleh pada ketebalan irisan nanas $3 \mathrm{~mm}$ dan suhu penggorengan $90^{\circ} \mathrm{C}$ yaitu $4,69 \%$. Kadar air ini memenuhi standar SNI 014304-1996 yang mensyaratkan kadar air keripik nanas maksimal 5\%. Grafik kadar air keripik nanas dapat dilihat pada Gambar 1 yang menunjukkan bahwa semakin tinggi suhu penggorengan dan semakin tipis irisan buah nanas maka kadar air keripik nanas semakin turun.

Koefisien korelasi $\left(R^{2}\right)$ menunjukkan kekuatan (strength) hubungan linear dan arah hubungan dua variabel acak. Interpretasi mengenai kekuatan hubungan antara dua variabel memberikan kriteria sebagai berikut: $R^{2}=0$ artinya tidak ada korelasi antara 2 variabel, $R^{2}=>0-0,25$ artinya korelasi sangat lemah, $R^{2}=>0,25-$ 0,5 artinya korelasi cukup, $R^{2}=>0,5-0,75$ artinya korelasi kuat, $R^{2}=>0,75-0,99$ artinya korelasi sangat kuat dan $R^{2}=1$ artinya korelasi sempurna (Sarwono, 2006). Pada Gambar 1 dapat dilihat bahwa $\mathrm{R}^{2}$ dengan korelasi yang sangat kuat adalah pada ketebalan irisan buah nanas $3 \mathrm{~mm}$ yaitu 0,944 sehingga dapat disimpulkan kadar air untuk irisan buah nanas dengan ketebalan 3 $\mathrm{mm}$ adalah yang terbaik.

\section{Kadar Abu}

Kadar abu difungsikan untuk mendeteksi kandungan mineral yang terdapat pada bahan makanan, baik itu yang berasal dari bahan makanan sendiri ataupun yang berasal dari mesin proses. Kadar abu yang sangat tinggi mengindikasikan bahwa telah terjadi kontaminasi bahan oleh alat karena adanya gesekan selama proses (Kurniawati, 2010). Menurut Rahmawati (2008), semakin tinggi suhu yang digunakan maka semakin besar air yang menguap sehingga mengakibatkan semakin besar kadar abu yang dihasilkan. Nilai parameter kadar abu hasil analisis yang tertera pada Tabel 2 menunjukkan bahwa semua perlakuan memenuhi SNI 01-4304-1996 yang mensyaratkan kadar abu keripik nanas maksimal 3\%, kecuali untuk ketebalan irisan nanas $4 \mathrm{~mm}$ dan suhu penggorengan $90^{\circ} \mathrm{C}$ yaitu $3,51 \%$. Grafik kadar abu keripik nanas dapat dilihat pada Gambar 2 yang menunjukkan bahwa semakin tinggi suhu penggorengan maka kadar abu keripik nanas juga semakin tinggi.

Koefisien korelasi $\left(R^{2}\right)$ untuk irisan buah nanas $4 \mathrm{~mm}$ merupakan korelasi yang sangat kuat yaitu $R^{2}=0,999$. Namun pada irisan nanas $4 \mathrm{~mm}$ dan suhu penggorengan $90^{\circ} \mathrm{C}$, perlakuan tersebut tidak memenuhi SNI 01-4304-1996, sehingga disimpulkan kadar abu untuk perlakuan irisan nanas dengan ketebalan $3 \mathrm{~mm}$ adalah yang terbaik dengan $R^{2}=0,624$ yang artinya terjadi korelasi kuat. 


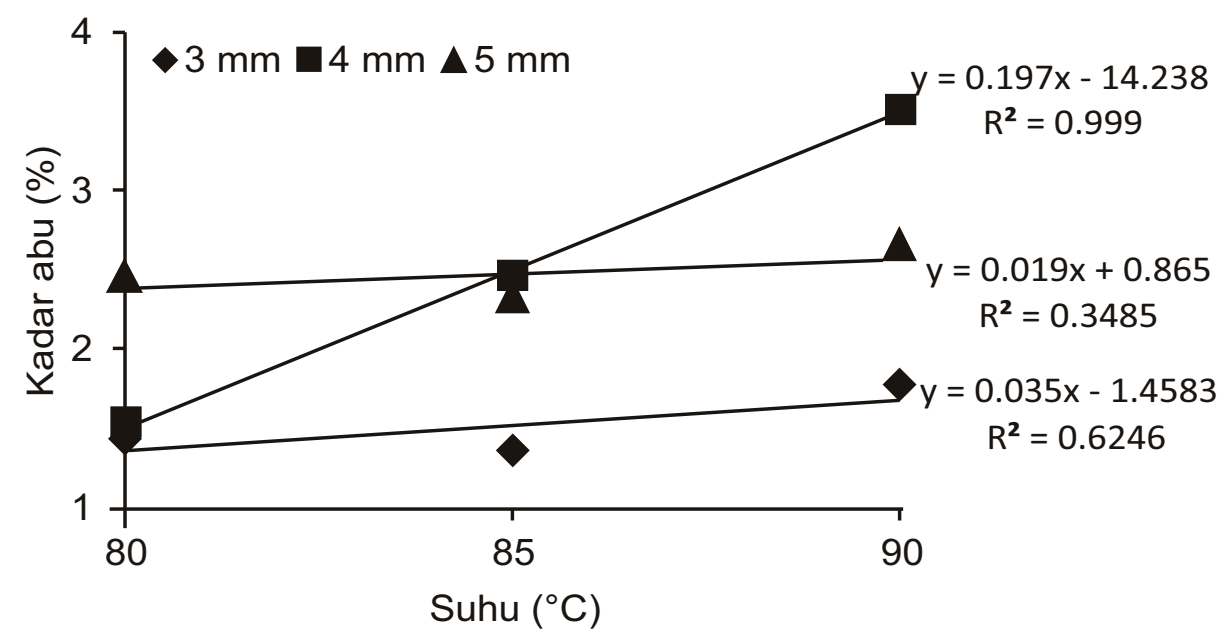

Gambar 2. Grafik kadar abu keripik nanas

\section{Kadar Minyak/lemak}

Menurut Jamaludin dkk. (2008), semakin tebal irisan buah dan suhu penggorengan semakin tinggi maka kadar minyak/lemak semakin tinggi. Proses penyerapan minyak terjadi ketika massa minyak secara perlahan masuk pada awal proses penggorengan ke dalam bahan yang digoreng, dan semakin meningkatnya suhu maka minyak/lemak semakin meningkat seiring dengan penurunan tekanan vakum. Massa minyak masuk ke dalam bahan yang digoreng dengan cara difusi, disebabkan karena adanya perbedaan konsentrasi massa minyak pada bagian permukaan dengan bagian dalam bahan. Proses penyerapan minyak pada bahan lebih cepat terjadi ketika penurunan kandungan kadar air bahan semakin rendah.
Kadar minyak/lemak keripik nanas pada Tabel 2 menunjukkan bahwa semakin tinggi suhu penggorengan untuk ketebalan irisan nanas $3 \mathrm{~mm}$ maka kadar minyak/lemak keripik nanas juga semakin tinggi. Namun, untuk ketebalan irisan nanas $4 \mathrm{~mm}$ dan 5 $\mathrm{mm}$, semakin tinggi suhu penggorengan maka kadar minyak/lemak menjadi turun, hal ini disebabkan pada ketebalan $4 \mathrm{~mm}$ dan 5 $\mathrm{mm}$ kandungan kadar airnya masih tinggi (Tabel 1). Kadar minyak/lemak hasil analisis pada Tabel 2 untuk semua perlakuan sudah memenuhi SNI 01-4304-1996 yang mensyaratkan kadar minyak/lemak keripik nanas maksimal 25\%. Grafik kadar minyak/lemak keripik nanas dapat dilihat pada Gambar 3. $R^{2}$ dengan korelasi sangat kuat yaitu 0,924 adalah pada perlakuan irisan nanas $3 \mathrm{~mm}$.

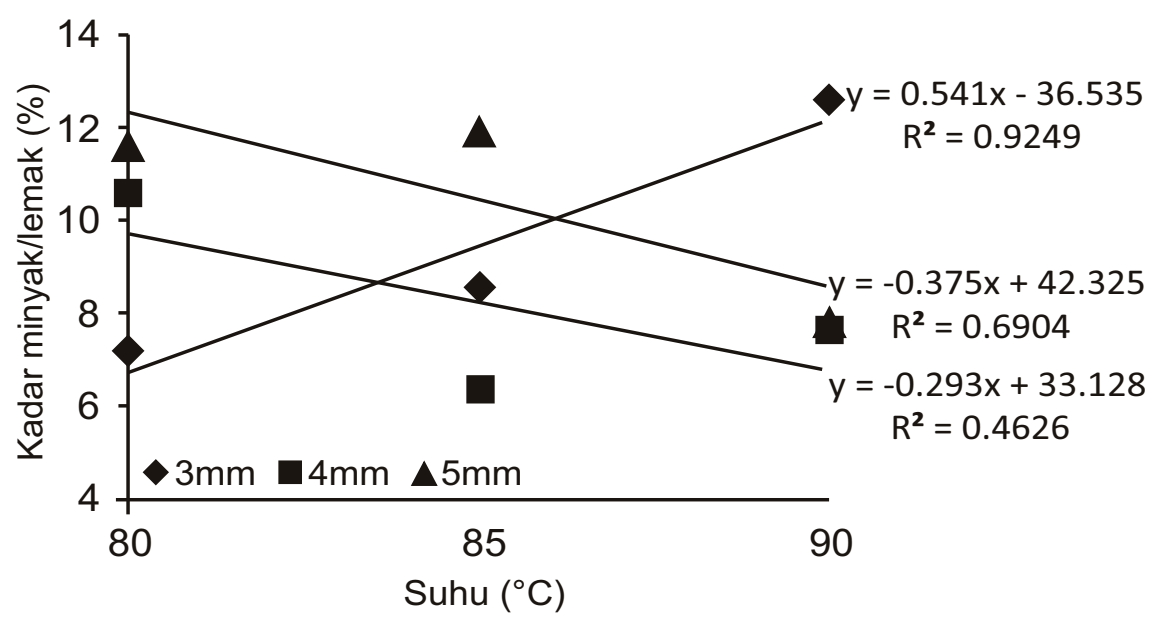

Gambar 3. Grafik kadar minyak/lemak keripik nanas 
Tabel 3. Hasil uji organoleptik keripik nanas

\begin{tabular}{|c|c|c|c|c|c|}
\hline \multirow{2}{*}{ Ketebalan Irisan (mm) } & \multirow{2}{*}{$\begin{array}{l}\text { Suhu } \\
\left({ }^{\circ} \mathrm{C}\right)\end{array}$} & \multicolumn{4}{|c|}{ Uji Organoleptik } \\
\hline & & Tekstur & Bau & Rasa & Warna \\
\hline \multirow{3}{*}{3} & 80 & Kurang renyah & \multirow{9}{*}{ Normal } & \multirow{9}{*}{ Khas } & \multirow{9}{*}{ Normal } \\
\hline & 85 & Renyah & & & \\
\hline & 90 & Renyah & & & \\
\hline \multirow{3}{*}{4} & 80 & Kurang renyah & & & \\
\hline & 85 & Kurang renyah & & & \\
\hline & 90 & Renyah & & & \\
\hline \multirow{3}{*}{5} & 80 & Kurang renyah & & & \\
\hline & 85 & Kurang renyah & & & \\
\hline & 90 & Renyah & & & \\
\hline SNI 01-4304-1996 & & Renyah & Normal & Khas & Normal \\
\hline
\end{tabular}

\section{Uji Organoleptik}

Hasil uji organoleptik dapat dilihat pada Tabel 3 yang menunjukkan bahwa untuk parameter bau, rasa dan warna, semuanya sudah memenuhi persyaratan mutu SNI. Hasil analisis untuk parameter tekstur, masih ada yang belum memenuhi persyaratan SNI. Perlakuan terbaik dari hasil uji organoleptik untuk keripik nanas adalah pada ketebalan irisan nanas $3 \mathrm{~mm}$ dan suhu penggorengan antara $85-90^{\circ} \mathrm{C}$, dimana tekstur yang diperoleh renyah, bau, rasa, dan warna khas buah nanas.

\section{KESIMPULAN}

Suhu penggorengan yang tepat untuk keripik nanas yang digoreng secara vakum adalah $85-90^{\circ} \mathrm{C}$. Sedangkan ketebalan irisan buah nanas yang tepat adalah $3 \mathrm{~mm}$. Kombinasi penggorengan buah nanas secara vakum ini adalah yang terbaik dan sudah memenuhi SNI 01-4304-1996.

\section{DAFTAR PUSTAKA}

Arif, Y. 2013. Keripik buah dari bahan alami. Jawa Timur. www.keripikbuaharif. blogspot.com. Diakses Tanggal 23 Juli 2013.
Badan Pusat Statistik 2013. Kalbar dalam angka. Pemerintah Daerah Provinsi Kalimantan Barat.

Badan Standardisasi Nasional. 1996. Keripik nanas. SNI 01-4304-1996. Jakarta: Badan Standardisasi Nasional.

Dwi. 2011. Cara membuat keripik buah dan s a y u r. w w w. F r e e 3 a I I pengatahuanku.blogspot.com. Diakses Tanggal 18 Januari 2013.

Jamaludin, R.B., Hastuti P., dan Rochmadi. 2008. Model matematik perpindahan panas dan mass a proses penggorengan buah pada keadaan hampa. Dalam: Prosiding Seminar Nasional Teknik Pertanian. Yogyakarta: Universitas Gajah Mada

Komunitas Agrobisnis. 2013. Peluang usaha, Re-Packing Keripik Buah. www.agromaret.com. Kota Malang. Jawa Timur.

Kurniawati, L. 2010. Pembuatan keripik ubi jalar (Ipomoea batatas) dengan vacuum fryer. Jurnal Kimia dan Teknologi. 
Lastriyanto A. 2006. Mesin penggorengan vakum (Vacuum Fryer). Malang: Lastrindo Engineering.

Muchtadi TR. 2008. Teknologi proses pengolahan pangan. 3rd ed. Bogor: Institut Pertanian Bogor.

Nurhudaya. 2011. Rekayasa penggorengan vakum dan pengemasan keripik durian Mentawai. Skripisi. Fakultas Teknologi Pertanian. IPB. Bogor.

Pangaila, Siko, T. 2010. Pengolahan buah nanas. http://epetani.deptan.go.id

Rahmawati, S. 2008. Penentuan lama pengeringan pada pembuatan serbuk biji alpukat (Persea Americana mill). Skripsi. Fakultas Teknologi Pertanian. Universitas Brawiajaya. Malang.
Sarwono, J. 2006. Metode penelitian kuantitatif dan kualitatif. Yogyakarta: Graha llmu.

Sudjud HR. 2000. Mempelajari pengaruh suhu dan waktu penggorengan hampa terhadap sifat fisik dan organoleptik keripik buah cempedak (Artocarpus integer (Thunb) Merr). Skripsi. Fakultas Teknologi Pertanian. IPB. Bogor.

Suseno SH, Jajang SM, Asra. 2008. Penerapan teknologi vacuum frying bagi kelompok tani pengolah ikan di Kabupaten Tasikmalaya dalam rangka pengembangan produk unggulan daerah. Laporan program penerapan IPTEKS. Lembaga penelitian dan pengabdian kepada masyarakat. IPB. Bogor. 